\title{
PENGEMBANGAN LKPD KONTEKSTUAL PADA MATERI SUHU, KALOR DAN PERPINDAHAN KALOR DI KELAS X SMA
}

\author{
Andriani ${ }^{1}$, Maison ${ }^{2}$, dan Rahma Dani ${ }^{3}$ \\ ${ }^{1,2,3}$ Program Studi Pendidikan Fisika FKIP Universitas Jambi, Jambi, Indonesia \\ Email: andrianidna@gmail.com
}

\section{Info Artikel}

Diterima:

5 November 2018

Disetujui:

10 April 2019

Dipublikasikan:

30 Juni 2019

\begin{abstract}
Abstrak:
Penelitian ini bertujuan untuk mengembangkan LKPD kontekstual pada materi suhu, kalor dan perpindahan kalor kelas X SMA dan untuk mengetahui persepsi peserta didik. Penelitian ini merupakan penelitian dan pengembangan yang menggunakan model pengembangan 4-D (Difine, Design, Develop, and Disseminate). Subjek uji coba pada penelitian ini adalah peserta didik kelas X SMA Negeri 1 Jujuhan Bungo. Instrumen penelitian berupa lembar validasi ahli dan angket persepsi peserta didik. Data dianalisis secara deskriptif. Produk yang dihasilakn berupa LKPD kontekstual pada materi suhu, kalor dan perpindahan kalor. Kegiatan pada LKPD sesuai dengan langkahlangkah pembelajaran kontekstual (konstruktivisme, inkuiri, bertanya, masyarakat belajar, pemodelan, refleksi dan penilaian). Hasil validasi ahli materi dan ahli media terhadap LKPD menyatakan layak untuk digunakan. Hasil persepsi peserta didik diperoleh rerata skor 4,27 (sangat baik).
\end{abstract}

Kata kunci: LKPD, Pembelajaran Kontekstual

\begin{abstract}
:
This research aims to develop contextual LKPD in temperature materials, heat and displacement of X-grade SMA and to know the perception of learners. This research is a research and development that uses 4-D development model (Difine, Design, Develop, and Disseminate). The subject of trials in this study was a student of $X$ grade SMA Negeri 1 Jujuhan Bungo. Research instruments in the form of expert validation sheets and student perception polls. Data is analyzed descriptively. The resulting product is a contextual LKPD on temperature material, heat and heat transfer. Activities on the LKPD in accordance with the steps of contextual learning (constructivism, Inquisition, questioning, learning society, modeling, reflection and assessment). The validation results of expert material and media experts against LKPD stated to be worthy of use. The results of the learner's perception gained an average score of 4.27 (very good).
\end{abstract}

Keywords: LKPD, contextual learning 


\section{Pendahuluan}

Lembar kerja peserta didik adalah bahan ajar yang sudah dikemas sedemikian rupa, sehingga peserta didik diharapkan dapat mempelajari materi ajar secara mandiri (Prastowo, 2011). Dalam LKPD, peserta didik akan mendapatkan materi, ringkasan dan tugas yang berkaitan dengan materi dan LKPD sangat sesuai digunakan peserta didik dalam kegiatan belajar, LKPD berisikan tugas-tugas materi pelajaran, dibidang ilmu pengetahuan alam dan masalah yang berkaitan dalam kehidupan sehari-hari.

Sesuai dengan hal tersebut Amri (2013), menjelaskan bahwa "dengan LKPD, guru dapat menyediakan materi pelajaran dengan aktivitas peserta didik". Dari penjelasan diatas terlihat bahwa LKPD yang dapat meningkatkan aktivitas peserta didik dan pemahaman konsep. Salah satu LKPD yang dapat meningkatkan aktivitas peserta didik dan pendekatan saintifik. Selain itu, melalui LKPD peserta didik berkesempatan untuk secara aktif dan kreatif terlibat dengan materi yang dibahas sehingga pembelajaran akan lebih bermakna.

Menurut Prastowo (2011), kerangka penyusunan LKPD adalah sebagai berikut:

a. Melakukan analisis kurikulum, meliputi langkah pertama dalam penyusunan LKPD.

b. Menyusun peta kebutuhan LKPD, meliputi jumlah LKPD yang harus ditulis serta melihat sekuensi atau urutan LKPDnya.

c. Menentukan judul-judul LKPD, meliputi ditentukan kompetensi-kompetensi dasar, materi-materi pokok atau pengalaman belajar yang terdapat dalam kurikulum.

d. Penulisan LKPD, meliputi merumuskan kompetensi dasar, menentukan alat penilaian, menyusun materi dan memperhatikan struktur LKPD.

Menurut Arikunto (2013), manfaat menggunakan media belajar LKPD adalah:

a. Meningkatkan motivasi peserta didik, dengan mengarahkan peserta didik belajar secara sendiri-sendiri sesuai kemampuan dan minatnya.

b. Membantu guru dalam menyusun rencana pembelajaran.

c. Sebagai pedoman guru dan peserta didik untuk menambah informasi tentang konsep yang dipelajari melalui kegiatan belajar secara sistematis. d. Peserta didik akan mendapatkan pengalaman yang sama mengenai suatu peristiwa dan memungkinkan terjadinya interaksi langsung dengan lingkungan sekitar.

Menurut Slameto (2013), pengaruh penggunaan LKPD adalah sebagai berikut:

a. Bagi peserta didik, untuk sarana baik dikelas, di ruang praktek maupun di luar kelas. Sehingga peserta didik berpeluang besar untuk mengembangkan kemampuan, menerapkan pengetahuan, melatih keterampilan, memproses sendiri dengan bimbingan guru untuk mendapatkan perolehannya.

b. Bagi guru, melalui lembar kerja peserta didik dalam menyelenggarakan kegiatan belajar mengajar sudah menerapkan metode membelajarkan peserta didik, dengan kadar keaktifan peserta didik yang tinggi. Dalam pengajaran mata pelajaran, media LKPD digunakan untuk memancing aktivitas belajar peserta didik. Karena dengan LKPD, peserta didikakan merasa diberi tanggung jawab moril untuk menyelesaikan suatu tugas dan merasa harus mengerjakannya, terlebih lagi apabila guru memberikan perhatian penuh terhadap hasil pekerjaan peserta didik dalam LKPD tersebut.

Berdasarkan hasil wawancara dengan salah satu guru fisika SMA Negeri 1 Jujuhan Bungo diperoleh informasi bahwa guru belum pernah menggunakan LKPD berbasis pembelajaran kontekstual dalam pembelajarannya. Guru juga masih menggunakan metode ceramah dalam menjelaskan materi, sehinggga peserta didik menjadi pasif dalam proses pembelajaran.

Berdasarkan hasil studi lapangan, dalam proses pembelajaran fisika telah menggunakan LKPD sebagai sumber belajar. Namun LKPD yang digunakan bukanlah LKPD yang dikembangkan oleh gurunya melainkan masih menggunakan LKPD yang disediakan oleh pemerintah yang disusun oleh Tim Citra Pustaka. Meskipun LKPD yang biasa digunakan dapat mendukung peserta didik dalam belajar, tetapi LKPD masih terdapat kekurangan karena ada materi pembelajaran yang tidak dijabarkan, gambar di LKPD tersebut masih minim, dan gambar yang ada pada umumnya berwarna hitam putih sehingga LKPD ini kurang menarik dan 
peserta didik juga kurang aktif dan kreatif dalam pembelajaran.

Menurut Trianto (2007) menjelaskan pembelajaran kontekstual atau contekstual teaching and learning (CTL) merupakan suatu konsepsi yang membantu guru mengkaitkan konten mata pelajaran dengan situasi dunia nyata dan memotivasi peserta didik membuat hubungan antara pengetahuan dan penerapannya Negara dan tenaga kerja. Menurut Amri (2010), komponen pembelajaran kontekstual adalah: konstruktivisme, inkuiri, quistioning (bertanya), learning community (masyarakat belajar), modelling (pemodelan), reflection (refleksi) dan authentic assessment (penilaian sebenarnya).

Menurut Sihotang, dkk (2012), tujuan pembelajaran kontekstual adalah:

"Pembelajaran Kontekstual adalah proses pendidikan yang bertujuan untuk membantu peserta didik melihat makna dalam materi akademik yang mereka pelajari dengan jalan menghubungkan mata pelajaran akademik dengan isi kehidupan sehari-hari yaitu dengan konteks kehidupan pribadi, sosial dan budaya. Pembelajaran kontekstual sebagai suatu pembelajaran yang memberikan fasilitas kegiatan belajar peserta didik untuk mencari, mengolah, dan menemukan pengalaman belajar yang lebih bersifat konkret (terkait dengan kehidupan nyata) melalui keterlibatan aktivitas peserta didik dalam mencoba, melakukan dan mengalami sendiri”.

$$
\text { Menurut Trianto (2007), }
$$

implementasi dari pembelajaran kontekstual adalah:

a) Mengembangkan pemikiran bahwa anak akan belajar lebih bermakna dengan cara bekerja sendiri,menemukan sendiri, dan mengkonstruksi sendiri pengetahuan dan ketrampilan barunya.

b) Melaksanakan sejauh mungkin kegiatan inquiri untuk semua topik.

c) Mengembangkan sifat ingin tahu siswa dengan bertanya.

d) Menciptakan masyarakat belajar.

e) Menghadirkan model sebagia contoh belajar.

f) Melakukan refleksi diakhir pertemuan.

g) Melakukan penialain yang sebenarnya dengan berbagai cara.

Menurut Widjajanti (2008), LKPD

juga harus memenuhi aspek-aspek penilaian.
Oleh karena itu, dalam menentukan kelayakan LKPD dalam penelitian ini melalui tahap validasi ahli dan uji coba produk. Validasi dilakukan kepada beberapa ahli yaitu ahli media dan ahli materi. Saran dan masukan dari para ahli menjadi acuan untuk melakukan revisi LKPD sebelum diuji cobakan LKPD.

Penelitian ini bertujuan untuk menghasilkan lembar kerja peserta didik berbasis pembelajaran kontekstual materi suhu, kalor dan perpindahan kalor dan mengetahui persepsi peserta didik terhadap lembar kerja peserta didik berbasis pembelajaran kontekstual materi suhu, kalor dan perpindahan kalor. Adapun manfaat dari penelitian ini yaitu menghasilkan prototipe LKPD berbasis pembelajaran kontekstual materi suhu, kalor dan perpindahan kalor.

\section{Metode Penelitian}

Model Pengembangan

Jenis penelitian ini adalah penelitian

dan pengembangan (Research and Development). Model pengembangan yang digunakan yaitu model Four-D(Thiagarajan, dkk, 1974).

1. Pendefinisian (Define)

Pada tahap ini dilakukan beberapa kegiatan yaitu:

a. Analisis Awal-Akhir

Analisis awal-akhir bertujuan untuk memunculkan dan menetapkan masalah dasar yang dihadapi dalam pembelajaran, sehingga diperlukan suatu pengembangan bahan ajar. Pada tahapan ini dilakukan observasi langsung dengan guru mata pelajaran fisika di SMA Negeri 1 Jujuhan Bungo dengan lembar yang terstruktur yang sudah terlampil. Namun LKPD yang digunakan bukanlah LKPD yang dikembangkan oleh gurunya melainkan masih menggunakan LKPD yang disediakan oleh pemerintah yang disusun oleh Tim Citra Pustaka tersebut berisi kompetensi dasar, ringkasan materi, tugas kelompok yang berisi tujuan percobaan, alat dan bahan, serta analisis. Selain itu, berdasarkan observasi dari LKPD yang digunakan peserta didik diketahui bahwa LKPD yang telah digunakan tidak cukup menarik, terlalu banyak penjelasan, gambar atau ilustrasi yang digunakan hanya sedikit, tidak berwarna dan kalimatnya sulit dimengerti. LKPD yang biasa digunakan dapat mendukung peserta didik dalam belajar, tetapi LKPD tersebut masih terdapat kekurangan karena ada materi pembelajaran 
yang tidak dijabarkan seperti pada materi tentang pemuaian dan perpindahan kalor, gambar di LKPD tersebut masih minim dan gambar yang ada pada umumnya berwarna hitam putih sehingga LKPD ini kurang menarik dan peserta didik juga kurang motivasi untuk belajar.

Berdasarkan hal diatas, maka diketahui beberapa hal yang dibutuhkan oleh guru dalam mengajar adalah bahan ajar yang dapat membantu peserta didik supaya dapat belajar mandiri, aktif dak kreatif dalam kegiatan belajar mengajar, sehingga proses pembelajaran berlangsung sesuai dengan kriteria kulikulum 2013.

b. Analisis Peserta Didik

Pada kegiatan ini dilakukan observasi untuk melihat karakteristik peserta didik berupa telaah karakteristik peserta didik yang meliputi perkembangan pengetahuan, sikap terhadap topik pembelajaran, tingkat perkembangan kognitif, keterampilan penyelesaian masalah latar belakang pengetahuan dan sosial budaya peserta didik. Berdasarkan observasi, diketahui bahwa peserta didik memiliki kemampuan akademik dan perkembangan kognitif yang beraneka ragam, hal tersebut terlihat dari hasil belajar peserta didik dan dari keikutsertaan peserta didik dalam proses belajar. Pada proses belajar terdapat peserta didik yang aktif dan ada peserta didik yang pasif. Beberapa peserta didik memiliki kemauan untuk lebih memahami materi yang diajarkan dengan bertanya kepada guru.

Adapun perkembangan kongnitif yang dimiliki peserta didik rata-rata hanya sampai pada proses pemahaman yaitu $\mathrm{C}$, dimana peserta didik hanya mampu mengingat berbagai informasi yang telah diterima sebelumnya, selain itu peserta didik hanya mampu menyerap pengertian dari halhal yang telah dipelajari atau mampu menjelaskan pengetahuan informasi yang telah diketahui dengan kata-kata sendiri.

Kemudian keterampilan yang dimiliki individu peserta didik dapat terlihat ketika peserta didik menyelesaikan masalah yang diberikan guru, baik itu dalam memberi pendapat, bertanya, menyelesaikan masalah dan mengerjakan praktikum. Dari kegiatan yang dilakukan selama proses belajar, peserta didik kurang menunjukkan keterampilan, hal tersebut disebabkan proses belajar bersifat teacher center.
Dengan menggunakan pembelajaran kontekstual mampu meningkatkan minat dan hasil belajar peserta didik kelas X di SMA Negeri 1 Jujuhan. Karena pembelajaran kontekstual adalah suatu konsep pembelajaran yang menekankan pada keterkaitan antara materi pembelajaran dengan kehidupan nyata, sehingga peserta didik mampu menghubungkan dan menerapkan kompetensi hasil belajar dalam kehidupan sehari-hari.

\section{c. Analisis Materi}

Analisis materi merupakan identifikasi konsep-konsep utama yang akan diajarkan dan menyusunnya secara sistematis serta mengaitkan konsep secara relevan. Analisis materi ditunjukan untuk mengidentifikasi, merinci dan menyusunnya secara sistematis konsep-konsep utama dari materi suhu, pemuaian, pengaruh kalor terhadap suatu zat dan perpindahan kalor. Analisis materi sesuai KI dan KD yang harus dicapai peserta didik. Artinya, materi yang ditentukan untuk kegiatan pembelajaran hendaknya materi yang benar-benar menunjang tercapainya standar kompeteni dan kompetensi dasar, serta tercapainya indikator. Ada 4 (empat) jenis materi pembelajaran, yaitu: 1) Fakta adalah segala hal yang berwujud kenyataan dan kebenaran, 2) Konsep adalah segala yang berwujud pengertian-pengertian baru yang bisa timbul sebagai hasil pemikiran, 3) Prinsip adalah berupa hal-hal utama, pokok dan memiliki posisi terpenting dan 4) Prosedur adalah langkah-langkah sistematis atau berurutan dalam mengerjakan suatu aktivitas dan kronologi suatu sistem.

d. Analisis Tugas

Pada tahap ini dilakukan identifikasi keterampilan-keterampilan utama yang diperlukan peserta didik yang akan dibuat dalam LKPD untuk meningkatkan prestasi belajar peserta didik. Adapun tugas yang perlu dikerjakan peserta didik berdasarkan indikator, antara lain: 1) peserta didik melakukan pengamatan, 2) peserta didik melakukan percobaan, 3) peserta didik mengerjakan soal, 4) peserta didik membuat kesimpulan.

e. Perumusan Tujuan Pembelajaran

Pada tahap ini dilakukan perumusan tujuan pembelajaran sebagai dasar untuk menyusun LKPD yang dibuat. Hal tersebut, agar LKPD yang dibuat sesuai dengan 
kebutuhan peserta didik. Adapun tujuan pembelajaran di LKPD sebagai berikut:

1) Peserta didik dapat menjelaskan pengertian suhu.

2) Peserta didik dapat menjelaskan skalaskala termometer.

3) Peserta didik dapat menjelaskan proses pemuaian.

4) Peserta didik dapat membedakan pemuaian panjang, luas dan volume.

5) Peserta didik dapat menjelaskan perubahan wujud zat.

6) Peserta didik dapat menjelaskan apaapa yang mempengaruhi kalor terhadap zat.

7) Peserta didik dapat menjelaskan Asas Black menggunakan kalimat sendiri dengan benar.

8) Peserta didik dapat membedakan wujud gas, cair dan padat.

9) Peserta didik dapat menjelaskan pengertian konduksi, konveksi dan radiasi.

10) Peserta didik dapat menyebutkan contoh perpindahan kalor konduksi, konveksi dan radiasi dalam kehidupan sehari-hari.

2. Perancangan (Design)

Pada tahapan desain, peneliti membuat rancangan dari LKPD yang akan dikembangkan. LKPD dirancang sesuai dengan hasil analisis yang telah dilakukan, dimana rancangan disesuaikan dengan kebutuhan peserta didik, silabus dan indikator pembelajaran yang ingin dicapai

a. Cover

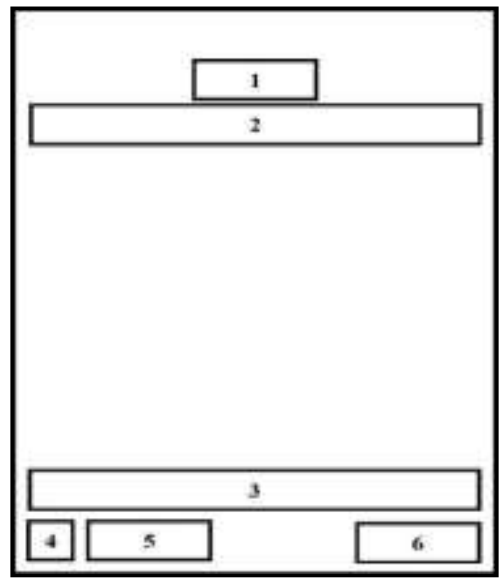

b. Desain awal pembelajaran (kompetensi inti, kompetensi dasar dan indikator)

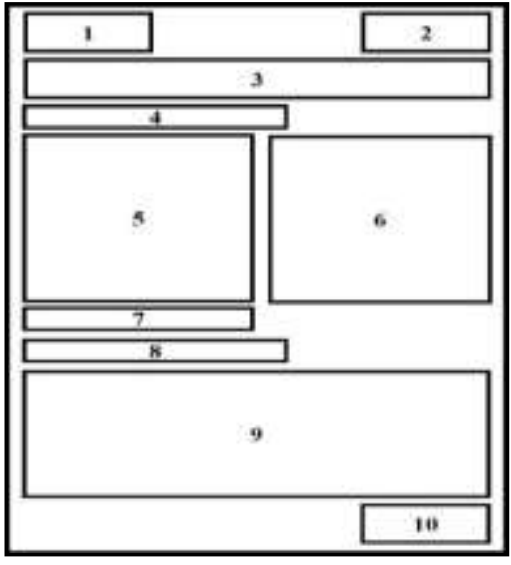

c. Desain awal pembelajaran (judul pembelajaran, tujuan dan uraian materi)

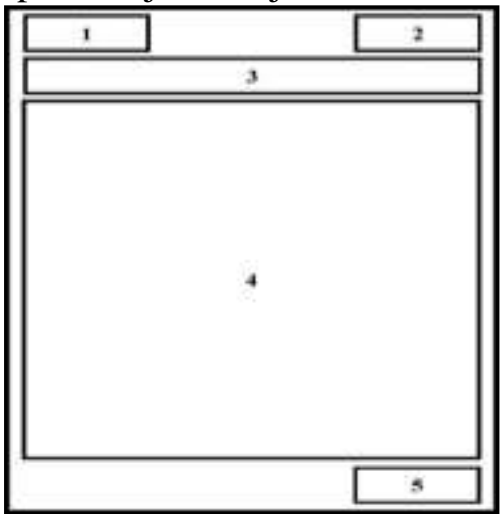

d. Desain awal pembelajaran (contoh soal dan kegiatan pembelajaran)

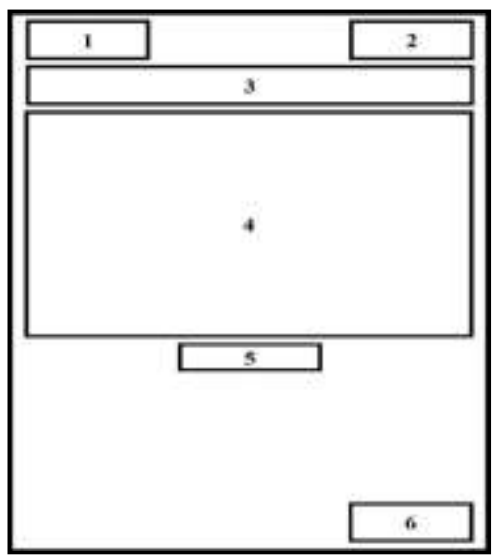

e. Desain awal pembelajaran (rangkuman dan uji kompetensi) 


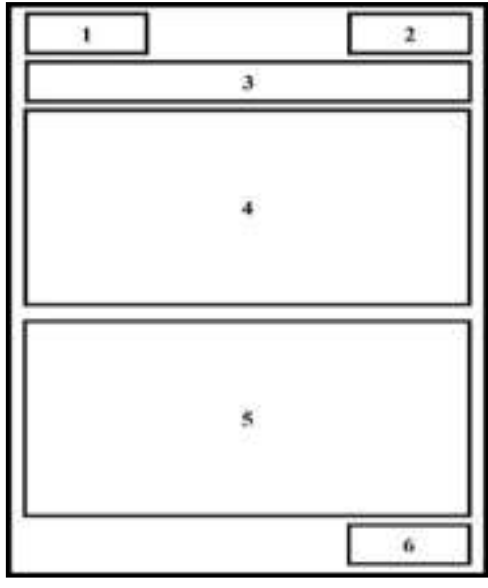

3. Pengembangan (Develop)

Pengembangan merupakan tahapan untuk menghasilkan produk pengembangan yang dilakukan melalui dua langkah, yakni: 1) penilaian ahli (expert appraisal) yang diikuti dengan revisi, 2) uji coba pengembangan (develomental testing).

Penilaian Ahli (Expert Apprasial)

Pada penilaian ahli ini dilakukan agar pengembangan yang dilakukan sesuai dengan kebutuhan peserta didik. Pada tahap ini disebut juga tahapan validasi. Validasi dilakukan yaitu validasi materi dan desain LKPD.

Uji Coba Pengembangan (Developmental Testing)

Tahap uji coba dilakukan setelah tahap validasi. Pada tahap ini, LKPD siap untuk diuji coba secara nyata pada kondisi yang sebenarnya. LKPD ini diuji coba pada peserta didik kelas X SMA Negeri 1 Jujuhan sebagai subjek penelitian. Peserta didik diminta untuk mengisi angket tentang persepsi peserta didik terhadap LKPD yang telah dibuat. Menggunakan angket tertutup, selanjutnya angket dianalisis reabilitas dan analisis dengan skala.

Uji Coba Produk

Uji coba produk merupakan bagian dari pengembangan produk pada tahapan uji coba pengembangan.

Desain Uji Coba

Adapun uji coba ini adalah uji coba kelompok kecil. Dengan melibatkan siswa dua kelas di SMP Negeri 11 Muaro Jambi Tahun Pelajaran 2016/2017. Kelas VIII B diberikan angket untuk mengukur reliabilitas. Sedangkan kelas VIII A untuk mengetahui persepsi siswa terhadap LKS yang dikembangkan.

Subjek Uji Coba
Dalam penelitian ini penulis melakukan uji coba melibatkan peserta didik dua kelas di SMA Negeri 1 Jujuhan Tahun Pelajaran 2017/2018. Yaitu kelas X B yang berjumlah 21 peserta didik dan kelas X A juga berjumlah 21 peserta didik. Kelas pertama, uji coba untuk mengetahui reabilitas angket. Kelas kedua, uji coba untuk mengetahui persepsi peserta didik terhadap LKPD yang dikembangkan.

Jenis Data

Jenis data yang digunakan pada penelitian ini bersifat kualitatif dan kuantitatif. Data kualitatif yang diambil adalah penilaian dari tim validasi ahli, sedangkan data kuantitatif yang diambil adalah persepsi peserta didik. Data yang diperoleh dari hasil pengembangan produk ini digunakan sebagai dasar dalam menetapkan kelayakan dan daya tarik produk yang dihasilkan terhadap LKPD fisika berbasis pembelajaran kontekstual yang telah dihasilkan.

Instrumen Pengumpulan Data

Instrumen untuk mengumpulkan data dalam penelitian pengembangan ini adalah menggunakan metode angket. Angket adalah sejumlah pertanyaan tertulis yang digunakan untuk memperoleh informasi dari responden dalam arti laporan tentang pribadinya atau hal-hal lain yang ingin responden ketahui. Penelitian ini menggunakan angket tertutup. Angket tertutup merupakan suatu angket di mana pertanyaannya disajikan sedemikian rupa sehingga responden diminta untuk memilih salah satu jawaban yang sesuai dengan karakteristik dirinya. Bentuk instrument pengumpulan data yang digunakan yaitu:

1. Angket lembar validasi untuk materi dan lembar validasi desain.

Tabel 1. Kisi-kisi validasi LKPD

\begin{tabular}{lll}
\hline \multicolumn{1}{c}{ Variabel } & Indikator & \multicolumn{1}{c}{ Deskriptor } \\
\hline $\begin{array}{l}\text { LKPD } \\
\text { berbasis }\end{array}$ & & \\
pembelajara & & \\
$\mathrm{n}$ & Isi, & a. Kesesuaian \\
kontekstual & Konstruk & b. Kemudahan \\
pada materi & si dan & c. Ketepatan \\
suhu, kalor & Bahasa & d.Kemanfaatan \\
dan & & \\
perpindahan & & \\
kalor & & \\
\hline
\end{tabular}

Sumber: (Riantoni, 2014) 
2. Angket persepsi peserta didik dengan perhitungan reabilitas.

Tabel 2. Kisi-kisi angket persepsi

\begin{tabular}{|c|c|}
\hline Indikator & Kriteria \\
\hline $\begin{array}{l}\text { Desain } \\
\text { pembelajaran }\end{array}$ & $\begin{array}{l}\text { a. Kejelasan tujuan } \\
\text { b. Ketepatan format } \\
\text { sajian } \\
\text { c. Kesesuai dengan } \\
\text { karakteristik peserta } \\
\text { didik }\end{array}$ \\
\hline Materi (content) & $\begin{array}{l}\text { d. Kebenaran materi } \\
\text { e. Kedalaman dan } \\
\text { keluasan materi } \\
\text { f. Kekomprehensifan } \\
\text { materi } \\
\text { g. Kesesuaian contoh, } \\
\text { ilustrasi dengan } \\
\text { materi } \\
\text { h. Tes, tugas latihan } \\
\text { mendukung } \\
\text { penguasaan materi }\end{array}$ \\
\hline Keterbacaan & i. Sruktur kalimat \\
\hline LKPD & $\begin{array}{l}\text { j. Kejelasan judul dan } \\
\text { sub judul } \\
\text { k. Sistematika } \\
\text { penyajian } \\
\text { 1. Susunan paragraph } \\
\text { m. Penggunaan kalimat } \\
\text { n. Penggunaan kata dan } \\
\text { istilah } \\
\text { o. Kemudahan bahasa } \\
\text { p. Kemenarikan dan } \\
\text { kesesuaian bahasa }\end{array}$ \\
\hline $\begin{array}{l}\text { Visualisasi } \\
\text { LKPD }\end{array}$ & $\begin{array}{l}\text { q. Menjelaskan materi } \\
\text { yang sulit } \\
\text { r. Mempermudah } \\
\text { pemahaman } \\
\text { s. Mendorong minat } \\
\text { peserta didik untuk } \\
\text { belajar } \\
\text { t. Memperkuat daya } \\
\text { ingat } \\
\text { u. Menyederhanakan } \\
\text { informasi yang sulit } \\
\text { v. Hambatan dan } \\
\text { kendala dalam } \\
\text { mempelajari LKPD }\end{array}$ \\
\hline
\end{tabular}

Sumber: (Warsita, B (2010)
Dalam penelitian ini reabilitas diukur dengan menggunakan rumus yang dikemukakan oleh Kuder dan Richardson. Rumus KR-20 ini cenderung memberikan hasil lebih tinggi dibandingkan dengan rumus yang lain. Mengukur reabilitas ditentukan dengan rumus Kuder Richardson (KR-20) menurut Sugiyono (2013) sebagai berikut:

$$
r_{11}=\left(\frac{n}{n-1}\right)\left(1-\frac{\Sigma \sigma_{i}^{2}}{\sigma_{t}^{2}}\right)
$$

Dengan $\quad S^{2}=\frac{\Sigma X^{2}-\frac{(\Sigma X)^{2}}{N}}{N}$

Keterangan:

$\mathrm{r}_{11}=$ indeks korelasi (harga reabilitas)

$\mathrm{n}=$ banyaknya butir soal

$\mathrm{p}=$ proporsi subjek yang menjawab item benar

$\mathrm{q}=1-\mathrm{p}=$ proporsi subjek yang menjawab item salah

$\Sigma p q=$ jumlah perkalian antara $\mathrm{p}$ dan

$\mathrm{N}$ = banyak peserta yang mengisi angket

$\mathrm{X}$ = skor yang diberikan

Koefisien reabilitas tes berkisar antara $0,00-1,00$ dengan perincian korelasi

Tabel 3. Kategori Reabilitas

\begin{tabular}{ll}
\hline $\begin{array}{l}\text { Kategori } \\
\text { Reabilitas }\end{array}$ & Keterangan \\
\hline $0,81<\mathrm{r} \leq 1,00$ & Sangat Tinggi \\
$0,61<\mathrm{r} \leq 0,80$ & Tinggi \\
$0,41<\mathrm{r} \leq 0,61$ & Sedang \\
$0,21<\mathrm{r} \leq 0,40$ & Rendah \\
$0,00<\mathrm{r} \leq 0,20$ & Sangat Rendah \\
\hline \multicolumn{2}{c}{ (Sumber: Arikunto, 2013) }
\end{tabular}

Teknik Analisis Data

Analisis data merupakan kegiatan untuk merubah data hasil dari penelitian menjadi informasi yang nantinya bisa digunakan dalam mengambil kesimpulan. Teknik analisis data pada penelitian ini terdiri atas analisis data kualitatif dan analisis data kuantitatif. Hasil validasi materi dan validasi desain menghasilkan analisis data kualitatif yang berupa deskriptif. Kegiatan analisis data kualitatif terdiri dari reduksi data, penyajian data, dan verifikasi (penarikan kesimpulan).

Reduksi data merupakan tahap merangkum, memilih hal-hal yang pokok, momfokuskan pada hal-hal yang penting, mencari tema dan serta menghasilkan pola. 
Dengan demikian data yang telah direduksi akan memberikan gambaran yang lebih jelas. Hasil reduksi data dalam bentuk rangkuman atau pola yang dihasilkan disajikan dalam bentuk teks. Tahap ini dinamakan dengan penyajian data dimana penyajian data tersebut berbentuk teks naratif. Tahap terakhir yaitu verifikasi atau penarikan kesimpulan. Rangkuman sebelumnya yang bersifat sementara diolah lagi dan didukung dengan bukti-bukti yang valid, maka didapat kesimpulan akhir.

Analisis data kuantitatif diperoleh dari angket persepsi peserta didik. Data yang dihasilkan dianalisis dengan deskriptif kuantitatif. Langkah-langkah menganalisis data angket persepsi siswa adalah sebagai berikut:

a) Mengkuantitatifkan hasil checking dengan memberi skor sesuai dengan bobot yang telah ditentukan sebelumnya.

b) Mencari skor rata-rata penilaian produk. Rumus yang digunakan:

$$
\bar{X}=\frac{\sum X}{n}
$$

Keterangan:

$\bar{X} \quad=$ skor rata-rata

$\mathrm{N}=$ jumlah responden

$\sum X=$ jumlah skor jawaban responden

c) Menentukan varian dan standar deviasi sampel.

$$
\begin{aligned}
& s^{2}=\frac{\sum\left(\mathrm{x}_{\mathrm{i}}-\bar{X}\right)^{2}}{(\mathrm{n}-1)} \\
& s=\sqrt{\frac{\sum\left(\mathrm{x}_{\mathrm{i}}-\bar{X}\right)^{2}}{(\mathrm{n}-1)}}
\end{aligned}
$$

Keterangan:

$$
\begin{array}{ll}
\mathrm{s}^{2} & =\text { standar deviasi kelompok } \\
\mathrm{s} & =\text { varians kelompok data } \\
\mathrm{n} & =\text { jumlah responden (validator) }
\end{array}
$$

d) Mengidentifikasi kecenderungan ubahan setiap sub variabel digunakan rata-rata ideal (Xi) dan standar deviasi ideal (SDi), dapat dihitung dengan norma yaitu:

$$
\text { Xideal }=\frac{1}{2}(\text { skor tertinggi }+ \text { skor terendah })
$$

SDi deal $=\frac{1}{6}$ (skor tertinggi - skor

\begin{tabular}{|c|c|c|c|}
\hline No & Interval Skor & $\begin{array}{l}\text { Nil } \\
\text { ai }\end{array}$ & $\begin{array}{l}\text { Kateg } \\
\text { ori }\end{array}$ \\
\hline 1 & $\mathrm{X}>\mathrm{Xi}+1,8 \mathrm{SBi}$ & A & Sangat Set \\
\hline 2 & $\begin{array}{l}\mathrm{Xi}+0,6 \mathrm{SBi}<\mathrm{X}= \\
\mathrm{Xi}+1,8 \mathrm{SBi}\end{array}$ & B & Setuju \\
\hline 3 & $\begin{array}{l}\mathrm{Xi}-0,6 \mathrm{SBi}<\mathrm{X}= \\
\mathrm{Xi}+0,6 \mathrm{SBi}\end{array}$ & $\mathrm{C}$ & $\begin{array}{l}\text { Cukup } \\
\text { Setuju }\end{array}$ \\
\hline 4 & $\begin{array}{l}\mathrm{Xi}-1,8 \mathrm{SBi}<\mathrm{X}= \\
\mathrm{Xi}-0.6 \mathrm{SBi}\end{array}$ & $\mathrm{D}$ & $\begin{array}{l}\text { Kurang } \\
\text { Setuju }\end{array}$ \\
\hline 5 & $\mathrm{X}=\mathrm{X} \mathrm{i}-1,8 \mathrm{SBi}$ & $\mathrm{E}$ & $\begin{array}{l}\text { Sangat } \\
\text { Tidak } \\
\text { Setuju }\end{array}$ \\
\hline
\end{tabular}

terendah) e) Nilai rata-rata total skor yang diperoleh, diubah menjadi data kualitatif berupa kriteria penilaian ideal. Pedoman kriteria ditunjukkan pada tabel:

Tabel 4. Kategori penilaian skala lima

\section{Hasil dan Pembahasan}

LKPD didesain dan dikembangkan sesuai dari hasil yang diperoleh pada tahapan pendefinisian dan desain. Untuk menyesuaikan apa yang telah dikembangkan dengan apa yang dibutuhkan peserta didik, maka dilakukan validasi sebanyak 3 kali validasi. Validasi yang dilakukan adalah validasi yang menyangkut tentang desain pembelajaran atau konstruk, materi serta komposisi dangkah scientific. Validasi dilakukan oleh 3 orang dosen Pendidikan Fisika Universitas Jambi. Validator akan memberikan saran, kritikan terhadap LKPD yang dikembangkan. Validasi dilakukan sampai validator menyatakan LKPD telah layak digunakan tanpa revisi.

\section{Validasi Materi dan Desain}

Pada validasi materi dan desain tahap I, validator menilai materi pada LKPD yang dikembangkan telah layak digunakan dengan beberapa revisi. Berdasarkan angket yang diberikan, validator menyarankan:

A. Memperbaiki kebenaran substansi materi pembelajaran seperti halnya ada beberapa persamaan/rumus yang belum jelas pada bagian materi kalor kekekalan energi kalor (Azas Black).

B. Memperbaiki tata urutan pelajaran yang sesuai dengan tingkat kemampuan peserta 
didik seperti pada daftar pustaka yang belum jelas.

C. Memperbaiki kompetensi dan indikator sesuai dengan silabus.I

D. Menambahkan gambar/ilustrasi untuk mempermudah pemahaman peserta didik dan juga mengkaitkan dengan kehidupan sehari-sehari, sehingga peserta didik lebih bisa memahami materi.

Pada validasi materi dan desain tahap II, validator masih menyarankan untuk perbaikan beberapa hal yaitu: Memperbaiki gambar yang terdapat di LKPD sehingga dapat membantu peserta didik memahami materi, Memperbaiki warna tulisan dan background LKPD agar jelas di baca, Memperbaiki kalimat sesuai dengan penggunaan kaidah Bahasa Indonesia yang benar. Pada validasi materi dan desain tahap III, validator menyatakan LKPD yang dikembangkan telah layak digunakan tanpa revisi.

Setelah LKPD divalidasi, kemudian dilakukan uji coba. Uji coba dilaksanakan di SMA Negeri 1 Jujuhan, yakni di 2 kelas, kelas $\mathrm{X}$ A yang berjumlah 21 peserta didik dan kelas X B yang juga berjumlah 21 peserta didik. Pada uji coba pertama dilakukan dikelas X B, dimana data yang diperoleh digunakan untuk melihat reabilitas angket yang digunakan. Reabilitas ini dihitung dengan menggunakan rumus Kuder Richardson (KR-20). Dari perhitungan dengan menggunakan rumus tersebut diperoleh nilai Reabilitas sebesar R11 = 0,7631 dengan kategori memiliki reabilitas tinggi. Maka disimpulkan angket penelitian memiliki ketepatan nilai meskipun angket digunakan berkali-kali untuk mengambil data non tes terhadap kelayakan bahan ajar yang telah dikembangkan.

Uji coba kedua dilakukan di kelas $\mathrm{X}$ A untuk melihat persepsi peserta didik terhadap LKPD yang dikembangkan. Angket yang digunakan terdiri dari 4 aspek yaitu desain pembelajaran yang terdiri dari 5 pertanyaan, materi terdiri dari 6 pertanyaan, keterbacaan LKPD terdiri dari 6 pertanyaan dan visualisasi LKPD juga terdiri dari 6 pertanyaan. Sehingga jumlah pertanyaan untuk ke-4 aspek ini yaitu 23 butir pertanyaan. Berdasarkan angket persepsi peserta didik didapatkan hasil data sebagai berikut:
Tabel 5. Hasil data angket persepsi

\begin{tabular}{rlcl}
\hline No & $\begin{array}{l}\text { Aspek } \\
\text { Pembelajaran }\end{array}$ & $\begin{array}{l}\text { Rata- } \\
\text { rata }\end{array}$ & Kriteria \\
\hline 1. & $\begin{array}{l}\text { Desain } \\
\text { Pembelajaran }\end{array}$ & 4,11 & Baik \\
2. & Materi & 4,31 & $\begin{array}{l}\text { Sangat } \\
\text { Baik }\end{array}$ \\
3. & $\begin{array}{l}\text { Keterbacaan } \\
\text { LKPD }\end{array}$ & 4,31 & $\begin{array}{l}\text { Sangat } \\
\text { Baik }\end{array}$ \\
4. & Visualisasi & 4,35 & $\begin{array}{l}\text { Sangat } \\
\text { Baik } \\
\text { SKPD }\end{array}$ \\
& Jumlah & $\mathbf{4 , 2 7}$ & $\begin{array}{l}\text { Sangat } \\
\text { Baik }\end{array}$ \\
\hline
\end{tabular}

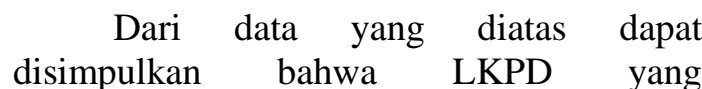
dikembangkan layak digunakan dengan kategori sangat setuju. Dari data di atas masih belum mencapai $100 \%$. Persentase yang kurang dari data merupakan kekurangan dari pengembangan LKPD ini. Kekurangan tersebut antara lain penggunaan bahasa, kesesuaian dengan karakteristik peserta didik dan informasi-informasi yang terdapat di dalam LKPD untuk menyelesaikannya.

\section{Kajian Produk Akhir}

Adapun spesifikasi dari LKPD yang telah dikembangkan sebagai berikut: di LKPD yang berisi tiga sub bab, yaitu suhu dan pemuaian, pengaruh kalor terhadap suatu zat dan perpindahan kalor. Setiap sub bab terdiri dari kompetensi dasar, indikator, informasi pendukung, langkah-langkah pembelajaran kontekstual (konstruktivisme, inkuiri, bertanya, masyarakat belajar, pemodelan, refleksi dan penilaian), contoh soal, latihan soal dan uji kompetensi. Keunggulan yang terdapat pada LKPD antara lain yaitu tahapan dari pembelajaran kontekstual yang disajikan jelas dan pada tahap informasi pendukung diberikan contoh-contoh peristiwa kehidupan seharihari yang berhubungan dengan materi yang dipelajari. Kelemahan yang terdapat pada LKPD ini yaitu kurangnya latihan-latihan soal yang disajikan sehingga peserta didik kurang terlatih mengerjakan latihan soal. 
1.

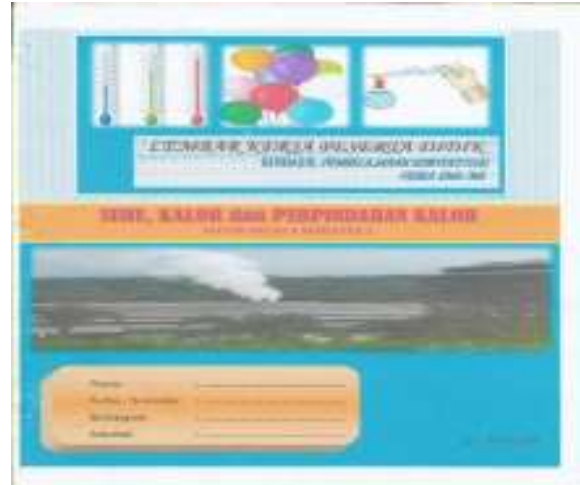

Halaman/lembar pertama berisi cover LKPD yaitu Judul, maa pelajaran, materi dan identitas peserta didik

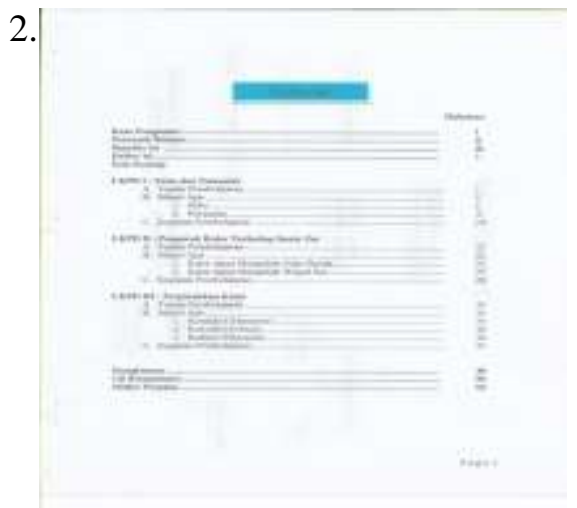

Halaman ini adalah daftar isi dari LKS yang berisi keterangan halaman dari isi LKS seperti halaman sub bab materi.

3.

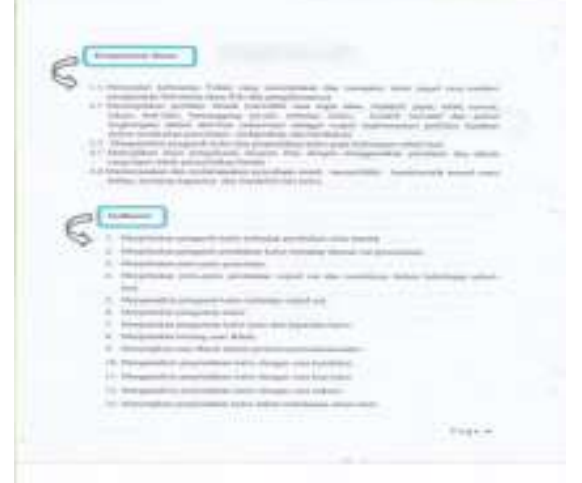

Halaman ini berisi kompetensi dasar dan indicator
4.

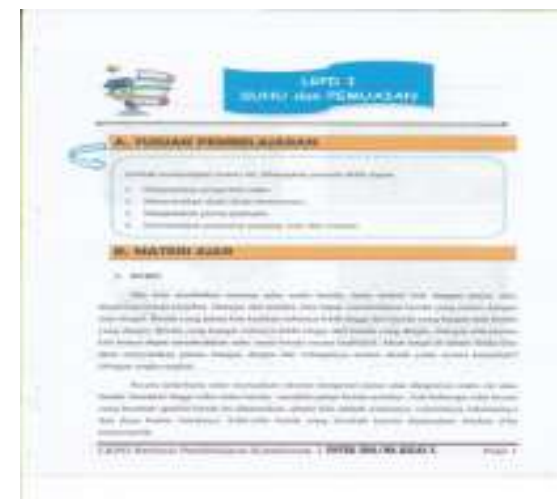

Halaman ini berisi judul materi, tujuan pembelajaran dan materi ajar.

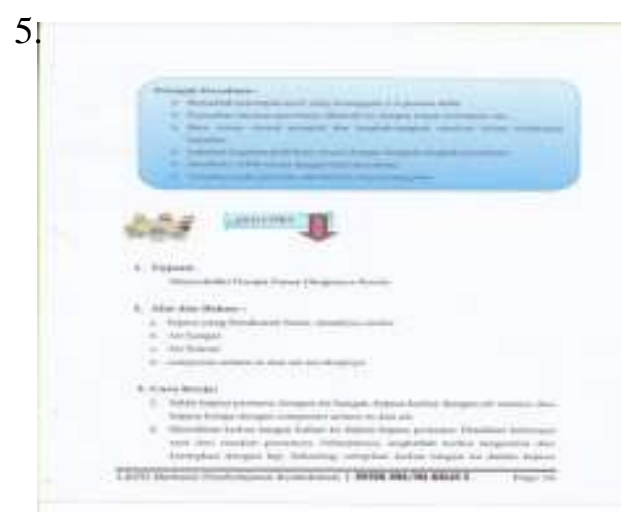

Halaman ini berisi petunjuk percobaan dan percobaan.

\section{Simpulan dan Saran}

Simpulan

Berdasarkan penelitian ini maka dihasilkan Lembar Kegiatan peserta didik (LKPD) berbasis pembelajaran kontekstual materi suhu, kalor dan perpindahan kalor yang valid dan layak digunakan. Spesifikasi yang terdapat di LKPD yang berisi tiga sub bab, yaitu suhu dan pemuaian, pengaruh kalor terhadap suatu zat dan perpindahan kalor. Setiap sub bab terdiri dari kompetensi dasar, indikator, informasi pendukung, langkahlangkah pembelajaran kontekstual (konstruktivisme, inkuiri, bertanya, masyarakat belajar, pemodelan, refleksi dan penilaian), contoh soal, latihan soal dan uji kompetensi. Keunggulan yang terdapat pada LKPD antara lain yaitu tahapan dari pembelajaran kontekstual yang disajikan jelas dan pada tahap informasi pendukung diberikan contoh-contoh peristiwa kehidupan sehari-hari yang berhubungan dengan materi 
yang dipelajari. Kelemahan yang terdapat pada LKPD ini yaitu kurangnya latihanlatihan soal yang disajikan sehingga peserta didik kurang terlatih mengerjakan latihan soal. Hasil validasi ahli desain dan ahli materi terhadap LKPD sudah dinyatakan layak digunakan. Hasil persepsi peserta didik pada uji coba adalah 4,27 yang dikategorikan sangat setuju.

Saran

Peneliti menyarankan kepada peneliti selanjutnya agar memperbanyak latihanlatihan soal pada LKPD berbasis pembelajaran kontekstual agar dapat meningkatkan kemampuan kognitifnya dalam memahami konsep materi yang dipelajari.

\section{Daftar Rujukan}

Amri,S \& Ahmadi, I. 2010 Proses Pembelajaran Kreatif dan Inovatif dalam Kelas. Jakarta: Prestasi Pustakaraya.

Arikunto, S. 2013. Dasar-Dasar Evaluasi Pendidikan. Jakarta: Bumi Aksara.

Isnanto, D. 2016. Pengembangan LKPD Berbasis Pendekatan Kontekstual Materi Kegiatan Ekonomi Di Indonesia. Universitas Negeri Yogyakarta. Yogyakarta. Di Akses 15 Januari 2017.

Riantoni, C. 2014. Pengembangan lembar kerja siswa berbasis inquiry terbimbing untuk eksperimen fisika SMP yang menggunakan phet interactive simulations pada materi listrik statis dan dinamis. Skripsi. Universitas Jambi. Jambi.

Sihotang, C \& Sibuea, A. 2012. Pengembangan Buku Ajar Berbasis Kontekstual Dengan Tema "Sehat Itu Penting". Universitas Negeri Medan. Medan. Di akses 22 Februari 2017.

Slameto. 2013. Belajar dan faktor-faktor yang mempengaruhinya. Jakarta: Rinaka Cipta.

Sugiyono. 2013. Metode Penelitian Kuantitatif, Kualitatif dan $R \& D$. Bandung: Alfabeta.
Thiagarajan, S., Semmel, D.S., Semmel, M.I. 1997. Instructional Develoment for Training Teachers of Exceptional Child-ren. Washington D.C: University Bloomingto.

Trianto. 2007. Model-Model Pembelajaran Inovatif Berorientasi Konstruktivistik. Jakarta: Prestasi Pustaka.

Prastowo, A. 2011. Panduan Kreatif Membuat Bahan Ajar Inovatif. Yogyakarta: DIVA Press.

Warsita, B. 2010. Teknologi Pembelajaran. Jakarta: PT Asdi Mahasalya.

Widjajanti, E. 2008. Kualitas Lembar Kerja Siswa. Makalah Seminar Pelatihan Penyusunan LKS untuk guru SMK/MAK pada kegiatan Pengabdian Kepada Masyarakat Jurusan Pendidikan FMIPA Universitas Negeri Yogyakarta. Yogyakarta. Di Akses 15 Januari 2017. 